\title{
Does the size of the microphytobenthic biofilm on intertidal mudflats depend on the available photosynthetic biomass?
}

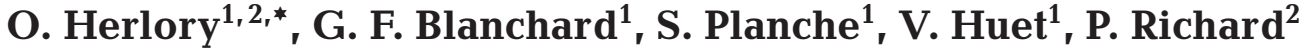 \\ ${ }^{1}$ Laboratoire de Biologie et Environnement Marins (LBEM), FRE 2727, CNRS-Université de La Rochelle, \\ Avenue Michel Crépeau, 17042 La Rochelle, France \\ ${ }^{2}$ Centre de Recherche sur les Ecosystèmes Marins et Aquacoles (CREMA), UMR 10, CNRS-IFREMER, BP5, \\ 17137 L'Houmeau, France
}

\begin{abstract}
Many scientists consider that the top centimetre of the sediment on intertidal mudflats contains the photosynthetic competent biomass (PCB). Part of this biomass migrates upward to the surface of the sediment during diurnal emersion periods to form a temporary biofilm: the photosynthetic active biomass (PAB). The present study tests the hypothesis that the size of the biofilm (PAB) is functionally dependent on PCB. Therefore, we have plotted PAB as a function of PCB for a range of different environmental conditions: 3 seasons and 5 tidal situations, representing a total of 600 cores. This investigation points out that, in spring and autumn, there was a simple linear relationship between $\mathrm{PAB}$ and $\mathrm{PCB}$, thus indicating that the maximum size of the biofilm represents a constant fraction (between 13 and $18 \%$ ) of the available biomass in the top centimetre of the mud. The relationship was more complex in winter, but the general trend remained the same. The dependence of the size of the biofilm on PCB might have important ecological implications in terms of primary productivity and also the monitoring of intertidal microalgal biomass at large spatial scales.
\end{abstract}

KEY WORDS: Microphytobenthos $\cdot$ Intertidal mudflat $\cdot$ Biomass $\cdot$ Biofilm $\cdot$ Functional relationship

\section{INTRODUCTION}

Benthic microalgae are generally the main primary producers in European intertidal mudflats. They constitute a significant amount of photosynthetic biomass in the uppermost centimetre of the mud, and are characterised by a large variability at different spatial and temporal scales (Colijn \& De Jonge 1984, De Jonge \& Colijn 1994, MacIntyre et al. 1996, Underwood \& Kromkamp 1999, Blanchard et al. 2001). Most of this biomass experiences aphotic conditions in the sediment because light usually does not penetrate below a depth of a few hundred microns into mud (Colijn 1982, De Jonge \& Colijn 1994). The majority of microalgae, down to a depth of 0.5 or $1 \mathrm{~cm}$, are nevertheless capable of a photosynthetic activity when they are artificially exposed to light (Riaux-Gobin et al. 1993,
Blanchard \& Cariou-Le Gall 1994), and this potential activity allows us to define this pool of microalgae as the 'photosynthetically competent biomass' (PCB) (MacIntyre \& Cullen 1995).

To cope with the restricted light conditions prevailing in intertidal mudflats within the sediment, the motile fraction of epipelic microalgae has developed an endogenous vertical migration rhythm, according to which part of the PCB moves upwards to the surface of the sediment during diurnal emersions to form a temporary biofilm (Serôdio et al. 1997, Perkins et al. 2001, Defew et al. 2002). This biofilm actually performs photosynthesis and represents the 'photosynthetically active biomass', or PAB (Guarini et al. 2000). At the end of low tide, 2 situations have been described so far: (1) microalgae migrate downward back into the sediment or (2) they can remain at the sediment surface. 
With the incoming tide they can be resuspended into the water column and then constitute an important food source for the pelagic trophic web (Consalvey et al. 2004b).

This basic pattern of vertical migration, which periodically transforms part of the PCB into PAB, has been qualitatively described many times by looking at the presence of microalgal cells or biomass at the surface of the sediment (Palmer \& Round 1965, 1967, Paterson et al. 1986, Serôdio et al. 1997, De Brouwer \& Stal 2001, Perkins et al. 2001, Tolhurst et al. 2003, Herlory et al. 2004) and has been reviewed recently by Consalvey et al. (2004b). However, the quantitative and dynamic aspects of the relationship between $\mathrm{PCB}$ and $\mathrm{PAB}$ have so far been overlooked. The question as to whether the biofilm size is independent or functionally dependent on the available PCB is fundamental for understanding the dynamics of the system's productivity. It is, therefore, necessary to determine, on a simple but general basis, how much of the PCB is actually mobilised in the biofilm to contribute to primary production.

Therefore, the objective of the present study is to determine the extent to which biofilm size is functionally dependent on the available PCB. Our investigation is based on the analysis of the concomitant variations of both PCB and PAB, to take advantage of the natural variability of microphytobenthic biomass at different scales. So, to ensure a large range of biomass variation, sampling was carried out over different seasons and tidal situations; on the spatial scale, local patchiness also accounts for the observed variability.

\section{MATERIALS AND METHODS}

Study site and sampling. The study was undertaken in Aiguillon Bay, which is located along the French Atlantic coast $\left(47^{\circ} 00^{\prime} \mathrm{N}, 1^{\circ} 05^{\prime} \mathrm{W}\right)$. The bay is dominated by bare intertidal mudflats composed of very fine muds (Lorin 1968). Sampling was performed in 3 different seasons (spring 2003, autumn 2003 and winter 2004). For each season, 5 samplings were carried out over half a lunar cycle (ca. 14 d): (1) at spring tides, (2) a few days after spring tides, (3) at neap tides, (4) a few days after neap tides and (5) at the following spring tides. In Aiguillon Bay, low tide occurs at midday during spring tides, so that there is only 1 long diurnal emersion period in the middle of the day, with a maximum sunlight input at the surface of the sediment. On the contrary, during neap tides, high tide occurs at midday, so that there are 2 short diurnal emersion periods, one early in the morning and the other late in the afternoon. Hence, the total amount of light that reaches the sediment surface during neap tides is lower than during spring tides.
For each diurnal emersion, sediment samples were collected within a $1 \mathrm{~m}^{2}$ quadrat. Ten $3 \mathrm{~cm}$ diameter cores were taken within this quadrat at each of the following times: at the beginning of emersion, $1 \mathrm{~h}$ after the beginning of air exposure, $1 \mathrm{~h}$ before immersion and at the end of emersion just before flooding time. For each core, the sediment was frozen with liquid nitrogen, so as not to disturb the microalgal assemblage. Cores were then stored in the dark at $-20^{\circ} \mathrm{C}$ until further processing.

Biomass measurements. Samples were freeze-dried before pigment analyses. For each core, 3 blocks were cut up $(8 \times 8 \mathrm{~mm}, 1.5 \mathrm{~cm}$ height $)$, then placed in a microtome and sectioned into a surface layer $(0$ to $200 \mu \mathrm{m})$ and a sub-surface layer $(200 \mu \mathrm{m}$ to $1 \mathrm{~cm})$. The sediment sectioned from the 3 blocks was then pooled for pigment analysis. Pigments were extracted in $90 \%$ acetone in the dark overnight at $5^{\circ} \mathrm{C}$, and then chl $a$ and pheopigments were detected fluorometrically and quantified using Lorenzen's (1966) equations. PAB was assumed to be in the upper $200 \mu \mathrm{m}$ layer and was expressed in milligrams of chl a per square metre per $200 \mu \mathrm{m}$; PCB was calculated as the sum of the surface and sub-surface layers and was expressed in milligrams of chl a per square meter per $1 \mathrm{~cm}$.

Statistical analyses. To test the relationship between the biofilm (PAB) and the available biomass (PCB), a Model II linear regression was applied, because both variables were random and measured with error. Linear regression parameters were estimated by the ranged major axis (RMA) method described in Legendre \& Legendre (1998) and computed according to Legendre's (2001) program¹.

\section{RESULTS AND DISCUSSION}

\section{Variability in the migration pattern and biofilm constitution}

The dynamics of the basic migration pattern, monitored over 3 seasons and under different tidal conditions, is presented in Fig. 1. The analysis of the results points out 4 main characteristics:

(1) Most importantly, for the different observed field situations (i.e. individual curves in Fig. 1), the highest value of $\mathrm{PAB}$ was very variable from one situation to the

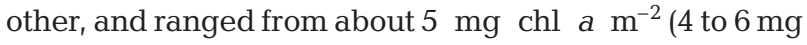

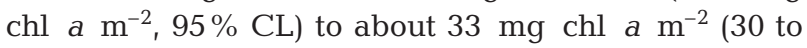
$36 \mathrm{mg}$ chl a m $\left.\mathrm{m}^{-2}, 95 \% \mathrm{CL}\right)$. As such, PAB is a very

\footnotetext{
${ }^{1}$ Legendre P (2001) Régression de modèle II-user's guide. Département de sciences biologiques, Université de Montréal. www.bio.umontreal.ca/legendre
} 


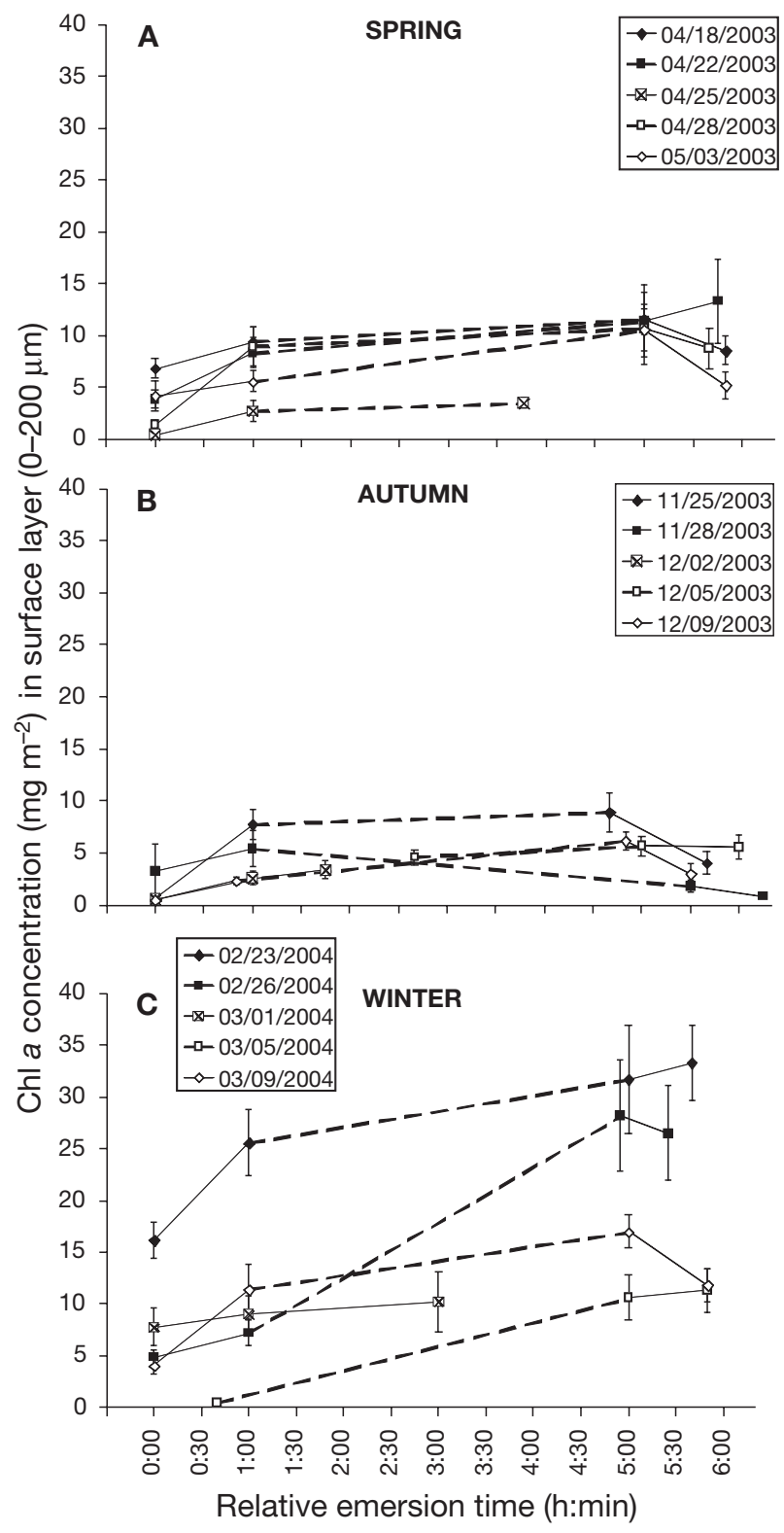

Fig. 1. Basic pattern of vertical migration and biofilm constitution during different diurnal emersion periods for 3 seasons: (A) spring, (B) autumn and (C) winter. For each season, 5 tidal conditions were monitored: $\bullet$ and $\diamond$ for spring tides, $\boldsymbol{\text { and }} \square$ between spring and neap tides, $\times$ for neap tides. For each emersion, biomass in the biofilm ( $\mathrm{mg} \mathrm{chl} a \mathrm{~m}^{-2}$ ) was measured at the beginning of the emersion, $1 \mathrm{~h}$ later, $1 \mathrm{~h}$ before immersion and just before the flooding tide

important state variable, which could be used to monitor the dynamics of the biofilm. This large variability of the biofilm size is in agreement with previous observations (De Brouwer \& Stal 2001, Honeywill et al. 2002).

(2) It appears that the combination of the tidal and diel cycles partly controlled the formation of the biofilm, since, for each season, the amount of PAB was the lowest when the duration of the diurnal emersion was shorter than $4 \mathrm{~h}$. So, for short diurnal emersions, there was only a very low mobilisation of microalgae to constitute the biofilm, which did not develop completely (Fig. 1A: 25 April 2003, Fig. 1B: 2 December 2003 and 5 December 2003, Fig. 1C: 1 March 2004). This is in agreement with the general observation that a minimum of light exposure is required for microalgae to move upwards (Round \& Palmer 1966, Consalvey et al. 2004b, Mitbavkar \& Anil 2004).

(3) When the duration of the diurnal emersion was longer than $4 \mathrm{~h}$, the biofilm developed during the first hour of emersion (80\% of observed situations). But the maximum amounts of PAB were measured $1 \mathrm{~h}$ before immersion (91\% of observed situations). These observations suggest that the biomass at the surface of sediment is very dynamic as observed by chlorophyll fluorescence imaging and LTSEM in Oxborough et al. (2000), Perkins et al. (2002), Consalvey et al. (2004a) or by chl a measurements in Herlory et al. (2004).

(4) Finally, at the end of the observed emersion periods, 2 situations can be distinguished (Fig. 1): on the one hand, the biofilm disappeared as epipelic microalgae left the sediment surface and buried into the mud (the biomass decreased in the upper $200 \mu \mathrm{m}$ during the last hour of emersion; 1 -tailed $t$-test, $\alpha<0.05$ ) in $50 \%$ of the observed situations; on the other hand, the biofilm remained at the sediment surface in the other $50 \%$ of the observed situations (the biomass did not decrease in the upper $200 \mu \mathrm{m}$ during the last hour of emersion; 1 -tailed $t$-test, $\alpha<0.05$ ). This apparent lack of downward migration has been observed in previous studies (Consalvey et al. 2004b and references therein).

\section{Testing the functional dependence of the biofilm on the available PCB}

PAB was plotted as function of PCB to test whether the size of the biofilm was functionally dependent on the available biomass in the top centimetre of the sediment (Fig. 2A). However, since the biofilm was very dynamic during emersion periods, only the maximum size values were taken into account (defined as the relevant variable, see above). Thus, the emersions, which did not allow the biofilm to develop completely, are not considered (25 April 2003, 2 December 2003, 5 December 2003 and 1 March 2004) (Fig. 2B).

Under such conditions, the results clearly show that, on a seasonal basis, there was a functional relationship between the maximum biomass that concentrated at the surface of the sediment and the total available biomass in the top centimetre of mud (Fig. 2B).

In spring and autumn, the functional relationship between PAB and PCB was determined by Model II linear regression, such that: 


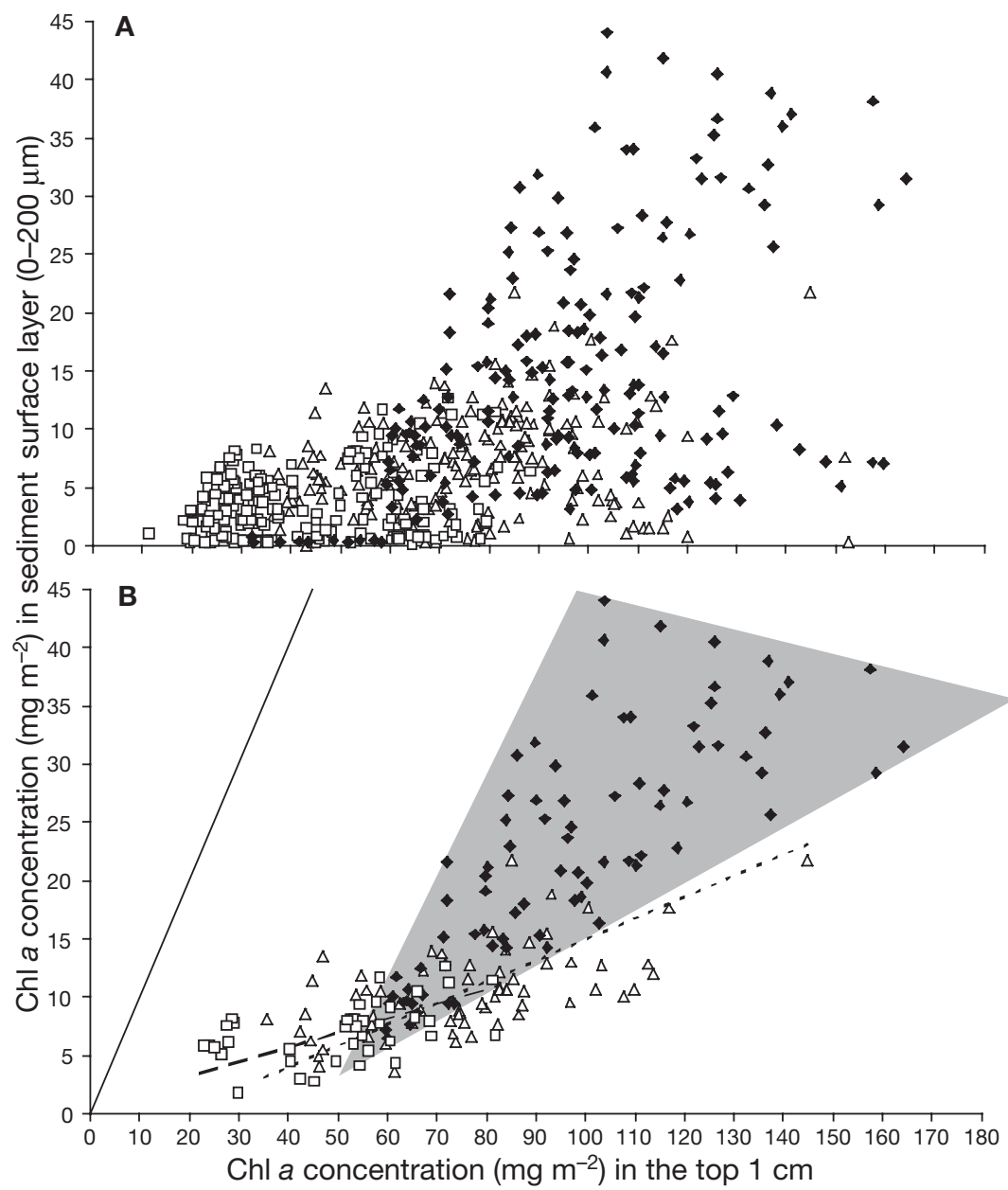

Fig. 2. PAB (photosynthetic active biomass, mg chl a $\mathrm{m}^{-2}$ per $200 \mu \mathrm{m}$ ) plotted as function of PCB (photosynthetic competent biomass, mg chl a $\mathrm{m}^{-2} \mathrm{~cm}^{-1}$ ) on a seasonal basis: individual observations are represented by $\Delta$ for spring, $\square$ for autumn and $\bullet$ for winter. In (A), all cores sampled in every season and tidal condition are displayed. In (B), only the maximum size values of biofilm are shown to characterise the statistical relationship between PAB and PCB (see 'Results and discussion' for details). Linear regressions are represented by dotted lines for spring and by dashed lines for autumn. In winter, the size of the biofilm was positively correlated with $\mathrm{PCB}$, but the increasing variability of $\mathrm{PAB}$ as a function of $\mathrm{PCB}$ did not allow adjustment of the linear regression. We drew an arbitrary box around the data, which assumes the shape of a triangle. The solid line represents the theoretical limit of the system should the entire biomass contained in the top centimetre of the mud (PCB) concentrate at the surface of the sediment to form a thick biomass layer (whatever its thickness, it is between the air and the sediment); as the biofilm is only a fraction of the PCB, the observed regression lines always have a coefficient $<1$

constant fraction of the biomass available in the top centimetre of the mud (PCB), over a large range of observed values (ca. 20 to

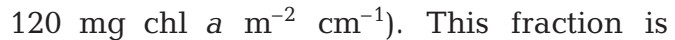
given by the regression coefficient and is about $18 \%( \pm 7 \%, 95 \% \mathrm{CL})$ in spring and almost $13 \%( \pm 7 \%, 95 \%$ CL) in autumn.

In winter, the relationship between the maximum size of the biofilm and $\mathrm{PCB}$ was more complex. There was still a positive correlation, but there was also an increase of PAB variability as a function of PCB. Consequently, it was not possible to adjust a simple relationship as for the other seasons. All observed winter data nevertheless fit within a well defined area: the grey triangle, which has been drawn around the data (Fig. 2B). The dispersion of the data in this area (Fig. 2B) shows that the variability of the maximum size of the biofilm increased up to about $100 \mathrm{mg} \mathrm{PCB} \mathrm{m} \mathrm{m}^{-2}$; then, beyond this threshold, the variability decreased because the dispersion of the data points suggests that the maximum size of the biofilm levelled out

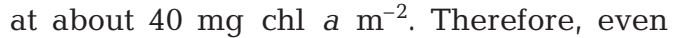
though the maximum size of the biofilm seems to depend on the available biomass in the top centimetre of the sediment (general trend), there was obviously at least another controlling variable, which could not be identified on the basis of the sampling strategy, but which accounted for the extra variability on a seasonal scale. These first results also raise the issue of the maximum amount of biomass that can concentrate at the surface of the sediment, whatever the available PCB.

\section{CONCLUSIONS}

The present results constitute the first report that, in some instances, there is a functional relationship between the maximum size that the biofilm can reach during emersions and the total available biomass in the sediment. However, even though they encompass various environmental conditions, they are based on observations from a

$$
\begin{aligned}
\mathrm{PAB}_{\text {spring }} & =0.18( \pm 0.07,95 \% \mathrm{CL}) \times \mathrm{PCB}-3.24 \\
( \pm 5.1,95 \% \mathrm{CL}) & \\
\mathrm{PAB}_{\text {autumn }} & =0.13( \pm 0.07,95 \% \mathrm{CL}) \times \mathrm{PCB}+0.78 \\
& ( \pm 3.6,95 \% \mathrm{CL})
\end{aligned}
$$

Such a linear model indicates that the maximum size of the biofilm during diurnal emersions tends to be a single site; therefore, additional investigations from different places are needed for further generalisation.

The variability in the maximum size of the biofilm is very likely to have a strong impact on its productivity, since the accumulation and packing of microalgal cells is known to induce auto-absorption of light and to decrease the photosynthetic yield (Hartig et al. 1998, 
Kromkamp et al. 1998, Barranguet \& Kromkamp 2000, Serôdio \& Catarino 2000, Honeywill et al. 2002). On the contrary, an increase of productivity is likely to occur since protection of the biofilm on the whole can be afforded by the uppermost cells in the biofilm (Perkins et al. 2001). It is therefore necessary to assess the physiological consequences of such variations, i.e. the quantification of the interactions between the structure and the function of the intertidal primary production system.

The existence of these kinds of simple relationships also has potentially very important consequences for the monitoring of the microphytobenthos. The use of remote sensing techniques (Paterson et al. 1998, Méléder et al. 2003a,b) now allows detection of chl a at the surface of the exposed sediment on intertidal mudflats; hence, assessment of biomass accumulated in the biofilm is possible. Therefore, the use of functional relationships such as those reported here, by deducing the total available biomass from that of the biofilm, really open new and important perspectives for monitoring microphytobenthic biomass at large spatial scales and at high frequency.

Acknowledgements. This study forms part of the $\mathrm{PhD}$ thesis of O.H. This work was financially supported by 'Ministère de la Jeunesse, de l'Education Nationale et de la Recherche'. The authors thank M. Bordes and R. Boutin (Centre Commun d'Analyses, University of La Rochelle) for their technical support in SEM observations. O.H. thanks J.-M. Guarini for his helpful advice.

\section{LITERATURE CITED}

Barranguet C, Kromkamp J (2000) Estimating primary production rates from photosynthetic electron transport in estuarine microphytobenthos. Mar Ecol Prog Ser 204: 39-52

Blanchard GF, Cariou-Le Gall V (1994) Photosynthetic characteristics of microphytobenthos in Marennes-Oleron Bay, France: preliminary results. J Exp Mar Biol Ecol 182:1-14

Blanchard GF, Guarini JM, Orvain F, Sauriau PG (2001) Dynamic behaviour of benthic microalgal biomass in intertidal mudflats. J Exp Mar Biol Ecol 264:85-100

Colijn F (1982) Light absorption in the waters of the EmsDollard estuary and its consequences for the growth of phytoplankton and microphytobenthos. Neth J Sea Res 15:196-216

Colijn F, De Jonge VN (1984) Primary production of microphytobenthos in the Ems-Dollard estuary. Mar Ecol Prog Ser 14:185-196

Consalvey M, Jesus B, Perkins RG, Brotas V, Underwood GJC, Paterson DM (2004a) Monitoring migration and measuring biomass in benthic biofilms: the effects of dark/ far-red adaptation and vertical migration on fluorescence measurements. Photosynth Res 81:91-101

Consalvey M, Paterson DM, Underwood GJC (2004b) The ups and downs of life in a benthic biofilm: migration of benthic diatoms. Diatom Res 19:181-202

De Brouwer JFC, Stal LJ (2001) Short-term dynamics in microphytobenthos distribution and associated extracellular carbohydrates in surface sediments of an intertidal mudflat. Mar Ecol Prog Ser 218:33-44

Defew EC, Paterson DM, Hagerthey SE (2002) The use of natural microphytobenthic assemblages as laboratory model systems. Mar Ecol Prog Ser 237:15-25

De Jonge VN, Colijn F (1994) Dynamics of microphytobenthos biomass in the Ems estuary. Mar Ecol Prog Ser 104:185-196

Guarini JM, Blanchard GF, Gros P, Gouleau D, Bacher C (2000) Dynamic model of the short-term variability of microphytobenthic biomass on temperate intertidal mudflats. Mar Ecol Prog Ser 195:291-303

Hartig P, Wolfstein K, Lippemeier S, Colijn F (1998) Photosynthetic activity of natural microphyto-benthos populations measured by fluorescence (PAM) and ${ }^{14} \mathrm{C}$-tracer methods: a comparison. Mar Ecol Prog Ser 166:53-62

Herlory O, Guarini JM, Richard P, Blanchard GF (2004) Microstructure of microphytobenthic biofilm and its spatio-temporal dynamics in an intertidal mudflat (Aiguillon Bay, France). Mar Ecol Prog Ser 282:33-44

Honeywill C, Paterson DN, Hagerthey SE (2002) Determination of microphytobenthic biomass using pulse-amplitude modulated minimum fluorescence. Eur J Phycol 37: 485-492

Kromkamp J, Barranguet C, Peene J (1998) Determination of microphytobenthos PSII quantum efficiency and photosynthetic activity by means of variable chlorophyll fluorescence. Mar Ecol Prog Ser 162:45-55

Legendre P, Legendre L (1998) Numerical ecology, 2nd English edn. Elsevier Science BV, Amsterdam

Lorenzen CJ (1966) A method for the continuous measurement of in vivo chlorophyll concentration. Deep-Sea Res 13:223-227

Lorin J (1968) Contribution à l'étude des transits sédimentaires dans la partie orientale duPertuis Breton et la baie de l'Aiguillon. Bull Inst Geol Bassin Aquitaine 5:111-139

MacIntyre HL, Cullen JJ (1995) Fine-scale vertical resolution of chlorophyll and photosynthetic parameters in shallowwater benthos. Mar Ecol Prog Ser 122:227-237

MacIntyre HL, Geider RJ, Miller DC (1996) Microphytobenthos: the ecological role of the 'secret garden' of unvegetated, shallow-water marine habitats. 1. Distribution, abundance and primary production. Estuaries 19:186-201

Méléder V, Barillé L, Launeau P, Carrère V, Rincé Y (2003a) Spectrometric constraint in analysis of benthic diatom biomass using monospecific cultures. Remote Sens Earth Resour Environ 88:386-400

Méléder V, Launeau P, Barillé L, Rincé Y (2003b) Microphytobenthos assemblage mapping by spatial visible-infrared remote sensing in a shellfish ecosystem. C R Biol 326: 377-389

Mitbavkar S, Anil AC (2004) Vertical migratory rhythms of benthic diatoms in a tropical intertidal sand flat: influence of irradiance and tides. Mar Biol 145:9-20

Oxborough K, Hanlon ARM, Underwood GJC, Baker NR (2000) In vivo estimation of the photosystem II photochemical efficiency of individual microphytobenthic cells using high-resolution imaging of chlorophyll a fluorescence. Limnol Oceanogr 45:1420-1425

Palmer JD, Round FE (1965) Persistent vertical-migration rhythms in benthic microflora. I. The effect of light and temperature on the rhythmic behaviour of Euglena obtusa. J Mar Biol Assoc UK 45:567-582

Palmer JD, Round FE (1967) Persistent vertical-migration rhythms in benthic microflora. VI. The tidal and diurnal nature of the rhythm in the diatom Hantzschia virgata. Biol Bull (Woods Hole) 132:44-55 
Paterson DM, Crawford RM, Little C (1986) The structure of benthic diatom assemblages: a preliminary account of the use and evaluation of low-temperature scanning electron microscopy. J Exp Mar Biol Ecol 95:279-289

Paterson DM, Wiltshire KH, Miles A, Blackburn J, Davidson I, Yates MG, McGrorty S, Eastwood JA (1998) Microbiological mediation of spectral reflectance from intertidal cohesive sediments. Limnol Oceanogr 43:1207-1221

Perkins RG, Underwood GJC, Brotas V, Snow GC, Jesus B, Ribeiro L (2001) Responses of microphytobenthos to light: primary production and carbohydrate allocation over an emersion period. Mar Ecol Prog Ser 223:101-112

Perkins RG, Oxborough K, Hanlon ARM, Underwood GJC, Baker NR (2002) Can chlorophyll fluorescence be used to estimate the rate of photosynthetic electron transport within microphytobenthic biofilms? Mar Ecol Prog Ser 228:47-56

Riaux-Gobin C, Wafar MVM, Klein B (1993) Production primaire potentielle microphytobenthique d'une slikke de nord Bretagne: stratification verticale. J Exp Mar Biol Ecol 169:215-231

Editorial responsibility: Otto Kinne (Editor-in-Chief), Oldendorf/Luhe, Germany
Round FE, Palmer JD (1966) Persistent, vertical migration rhythms in benthic microflora. II. Field and laboratory studies on diatoms from the banks of the river Avon. J Mar Biol Assoc UK 46:191-214

Serôdio J, Catarino F (2000) Modelling the primary productivity of intertidal microphytobenthos: time scales of variability and effects of migratory rhythms. Mar Ecol Prog Ser 192:13-30

Serôdio J, Silva JM, Catarino F (1997) Nondestructive tracing of migratory rhythms of intertidal benthic microalgae using in vivo chlorophyll a fluorescence. J Phycol 33: $542-553$

Tolhurst TJ, Jesus B, Brotas V, Paterson DM (2003) Diatom migration and sediment armouring - an example from the Tagus Estuary, Portugal. Hydrobiologia 503:183-193

Underwood GJC, Kromkamp J (1999) Primary production by phytoplankton and microphytobenthos in estuaries. In: Nedwell DB, Raffaelli DG (eds) Estuaries. Advances in ecological research, Vol 29. Academic Press, London, p 330

Submitted: January 10, 2005; Accepted: May 26, 2005 Proofs received from author(s): August 8, 2005 